\title{
Coproduction of DRI Powder and Semi-coke from Siderite Ore and Low Rank Coal by Excessive Coal-based Direct Reduction in Rotary Kiln
}

\author{
Yanhong LUO, Deqing ZHU, Xianlin ZHOU, * Bengjing SHI and Feng ZHANG \\ School of Minerals Processing and Bioengineering, Central South University, Lushan South Road 932, Yuelu District, \\ Changsha, 410083 China.
}

(Received on June 29, 2015; accepted on October 7, 2015; J-STAGE Advance published date: November 26, 2015)

\begin{abstract}
Effective utilization of low grade iron ore and low rank coal by excessive coal-based direct reduction process to coproduce DRI powder and semi-coke can be one of the solutions to cut the high cost of DRI powder and solve the problem of DRI shortage in the steelmaking industrial in China. In this paper, an integrated process was developed to beneficiate low grade siderite ore and upgrade inferior coal simultaneously to yield DRI powder and semi-coke. Based on bench scale results, the pilot scale verification tests were conducted and the final DRI concentrate assaying $92.62 \% \mathrm{Fe}_{\text {total, }}$ 93.51\% metallization degree was obtained at total iron recovery of $82.98 \%$. Meanwhile, C/Fe mass ratio was elevated to 2.50 in the direct reduction of siderite to generate semi-coke as by-product, which contained $76.11 \%$ fixed carbon. Based on the characterization of the semi-coke, it can be used as solid fuel in the iron ore sintering to replace coke breeze and cut production cost. The integrated process provides an attractive way to manufacture good quality burdens for electric furnace and alternative solid fuel for metallurgy industry.
\end{abstract}

KEY WORDS: siderite; low rank coal; coal-based direct reduction; DRI; semi-coke; rotary kiln.

\section{Introduction}

With the extensive mining of high grade iron ore resources, the average iron grade of minable iron ore reserves is only about $30 \%$ in China. Low grade ore is available abundantly, but it is used ineffectively due to the difficulties in ore preparations. As one of important iron ore resources, siderite ore is abundant in China with proven reserve of 1.83 billion tons, occupying $14 \%$ of total iron ore reserves. ${ }^{1,2)}$ However, siderite is refractory to beneficiate and has hardly been employed in iron production mainly due to its characterization that higher loss on ignition (LOI), low iron grade, decompositions of carbonate, and a significant amount of substitutions of $\mathrm{Mg}, \mathrm{Ca}$ and $\mathrm{Mn}$ for $\mathrm{Fe}$ in isomorphism in the siderite lattice. The high grade siderite directly used for ironmaking is less than $10 \%$ of its total reserves. ${ }^{3)}$ Since siderite is difficult to upgrade by traditional beneficiation technologies, such as flotation, gravity separation, magnetic separation or the combinative processes of these technologies, it is urgent to develop of an effective way to utilize siderite resource. In recent years, extensive researches have been focused on pyrometallurgical processes and such as magnetizing roasting-magnetic separation and direct reduction-magnetic separation process. $^{3-9)}$ For DRI production process of siderite, $\mathrm{Zhu}^{6)}$

\footnotetext{
* Corresponding author: E-mail: xlzhou_csu@csu.edu.cn DOI: http://dx.doi.org/10.2355/isijinternational.ISIJINT-2015-390
}

obtained sponge iron powder with iron grade in range of $84.85 \%-88.50 \%$ and metallization degree above $90 \%$ after magnetic separation of coal-based reduction of siderite in a fixed bed reactor. $\mathrm{Wei}^{7}$ crushed the siderite ore to $-2 \mathrm{~mm}$ and blended it with binder and coal, and pressed them into briquettes, then reduced with some external coal added, the final product assaying $92.76 \%$ of iron grade and $85.97 \%$ of iron recovery was obtained. DRI product was produced by Zhang $^{8)}$ at $1100^{\circ} \mathrm{C}$ from siderite with metallization degree up to $85 \%$. Yan $^{9)}$ reduced lean siderite with coal from Xinjiang at $1200^{\circ} \mathrm{C}$ and a good DRI powder was obtained. However, iron grade of DRI made by Zhu is lower than $90 \%$, and reduction temperature at $1200^{\circ} \mathrm{C}$ both from Wei and Yan may easily cause ring formation when using rotary kiln. These processes are problematic with lower iron grade of product or heavy energy-consuming and high production cost.

On the other hand, production of steel is highly dependent on the coke that acts as a reduction agent in blast furnace. ${ }^{10)}$ The price of coking coal is increasing due to the high consumption rate and limited resource. In order to reduce the cost of raw materials, low rank coal, which is cheaper and more abundant than high rank coal, should be used in the ironmaking process. Besides, the good quality DRI product for electric arc furnace is insufficient with great demand of about 2000 tons per year in China. Therefore, the coalbased direct reduction process is a quite suitable way to utilize the refractory iron ores. 
Recently, our group has conducted some trials on the beneficiation of some domestic siderite, and the results turned out to be satisfactory. ${ }^{11,12)}$ On the basis of forementioned facts related to the iron resources and low rank coal utilization problem and our previous study, a new concept is proposed to coproduce DRI concentrate and high carbon semi-coke in one process from low grade siderite ore and low rank coal. An integrated process of excessive coal-based direct reduction in rotary kiln is developed in both bench scale and pilot scale. The siderite iron ore was reduced by coal at over dosage to produce good quality DRI powder. Whilst the over dosage inferior coal was upgraded in the reduction process to generate high value semi-coke as by product that is a relatively cleaner solid fuel. In the direct reduction process, the excessive dosage of coal was intentionally added for both the direct reduction of iron ore and coking simultaneously. This operation aimed at providing strong reduction atmosphere for iron ore reduction and removing the risk of ring formation in rotary kiln, and enhancing coal coking to form semi-coke by-product to offset the cost of excess lump coal for reduction. Our final goal is to realize the clean and effective utilization of the refractory iron ores and low rank coal resources.

\section{Experimental}

\subsection{Raw Materials}

Siderite $\left(\mathrm{FeCO}_{3}\right)$ is an authigenic iron-bearing carbonate common in many diverse sedimentary settings. Crystals of $\mathrm{FeCO}_{3}$ have the rhombohedral $\mathrm{R}-3 \mathrm{c}$ structure at room temperature. ${ }^{13)}$ A Chinese domestic Xinjiang siderite lump ore was used as the feed to be reduced. The chemical compositions (Table 1) exhibit the iron grade is lower, assaying $35.43 \% \mathrm{Fe}_{\text {total }}$. The major impurities include silica, calcium, magnesium, manganese and alumina. The detrimental element content of phosphorus and sulfur are $0.033 \%$ and $0.24 \%$, respectively. The sample possesses high loss on ignition (LOI) of $28.89 \%$. The mineral compositions of siderite sample (Fig. 1) were studied by XRD which indicated the main minerals are siderite, calcite and quartz. Based on our previous study, ${ }^{11)}$ it is observed that siderite mineral is associated with quartz and calcite tightly, and has finegrained dissemination. Meanwhile, calcium, manganese and magnesium exist in iron carbonate in isomorphism, leading to difficulty in beneficiating siderite resource by traditional beneficiation processes.

Two low rank coals, Xinjiang lignite and Shenfu bitumite coal, were used as reductant in these experiments. They have similar fixed carbon and volatile around 53\% and 30\%, respectively, and low sulfur content less than $1 \%$ (Table 2). The Shenfu bitumite contains lower ash and sulfur content than Xinjiang lignite. The coals were considered as appropriate reductant with low coking index and high soft smelting temperature over $1180^{\circ} \mathrm{C}$.

A Limestone was used as desulfurizer which was crushed to $-5 \mathrm{~mm}$. The chemical compositions of desulfurizer are listed in Table 3. The size distributions of raw materials are presented in Table 4.

\subsection{Procedure of Experiment}

The test flow sheet of excessive coal-based direct reduction process to coproduce DRI powder and semi-coke is presented in Fig. 2. Firstly, siderite lump ore was charged

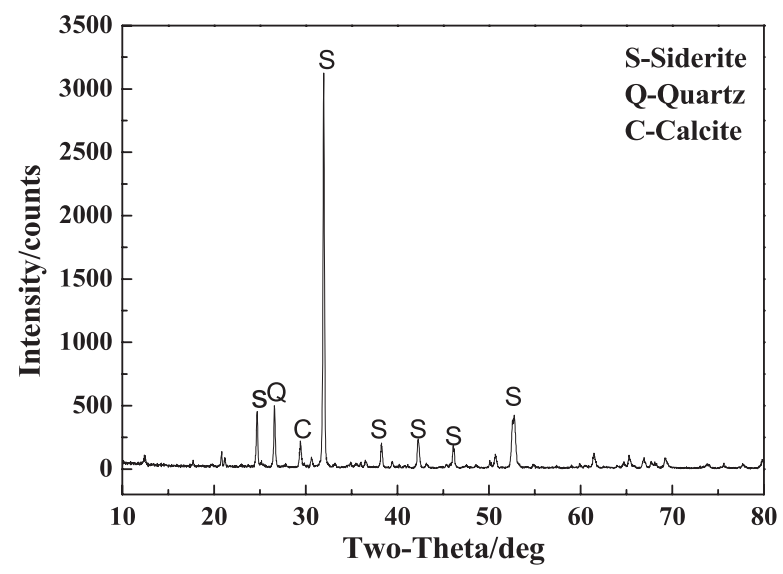

Fig. 1. XRD pattern of siderite sample.

Table 3. Chemical compositions of desulfurizer (mass\%).

\begin{tabular}{ccccccc}
\hline $\mathrm{SiO}_{2}$ & $\mathrm{Al}_{2} \mathrm{O}_{3}$ & $\mathrm{CaO}$ & $\mathrm{MgO}$ & $\mathrm{P}$ & $\mathrm{S}$ & LOI \\
\hline 3.74 & 0.48 & 51.83 & 0.20 & 0.048 & 0.039 & 40.04 \\
\hline
\end{tabular}

Table 4. Size distribution of raw materials (mass\%).

\begin{tabular}{ccccccc}
\hline \multirow{2}{*}{ Samples } & \multicolumn{6}{c}{ Size distribution/mm } \\
\cline { 2 - 7 } & $25-16$ & $16-10$ & $10-5$ & $5-3$ & $3-1$ & -1 \\
\hline Siderite & 54.40 & 27.80 & 17.80 & 0 & 0 & 0 \\
Shenfu bitumite & 33.33 & 33.33 & 33.34 & 0 & 0 & 0 \\
Xinjiang lignite & 33.33 & 33.33 & 33.34 & 0 & 0 & 0 \\
Desulphurizer & 0 & 0 & 0 & 42.41 & 27.49 & 30.10 \\
\hline
\end{tabular}

Table 1. Chemical compositions of siderite lump ore (mass\%)

\begin{tabular}{cccccccccc}
\hline $\mathrm{TFe}$ & $\mathrm{FeO}$ & $\mathrm{SiO}_{2}$ & $\mathrm{Al}_{2} \mathrm{O}_{3}$ & $\mathrm{CaO}$ & $\mathrm{MgO}$ & $\mathrm{MnO}$ & $\mathrm{P}$ & $\mathrm{S}$ & LOI \\
\hline 35.43 & 39.35 & 10.75 & 2.66 & 4.91 & 1.38 & 2.36 & 0.033 & 0.24 & 28.89 \\
\hline
\end{tabular}

Table 2. Proximate analysis of coal samples.

\begin{tabular}{ccccccc}
\hline Reductants & $\mathrm{M}_{\mathrm{ad}} / \%$ & $\mathrm{~V}_{\mathrm{ad}} / \%$ & $\mathrm{~A}_{\mathrm{ad}} / \%$ & $\mathrm{FC}_{\mathrm{ad}} / \%$ & $\mathrm{~S}_{\mathrm{tad}} / \%$ & Coking index \\
\hline Xinjiang lignite & 7.52 & 29.59 & 9.90 & 52.99 & 0.62 & 2 \\
Shenfu bitumite & 12.98 & 30.41 & 4.49 & 52.12 & 0.34 & 2 \\
\hline
\end{tabular}




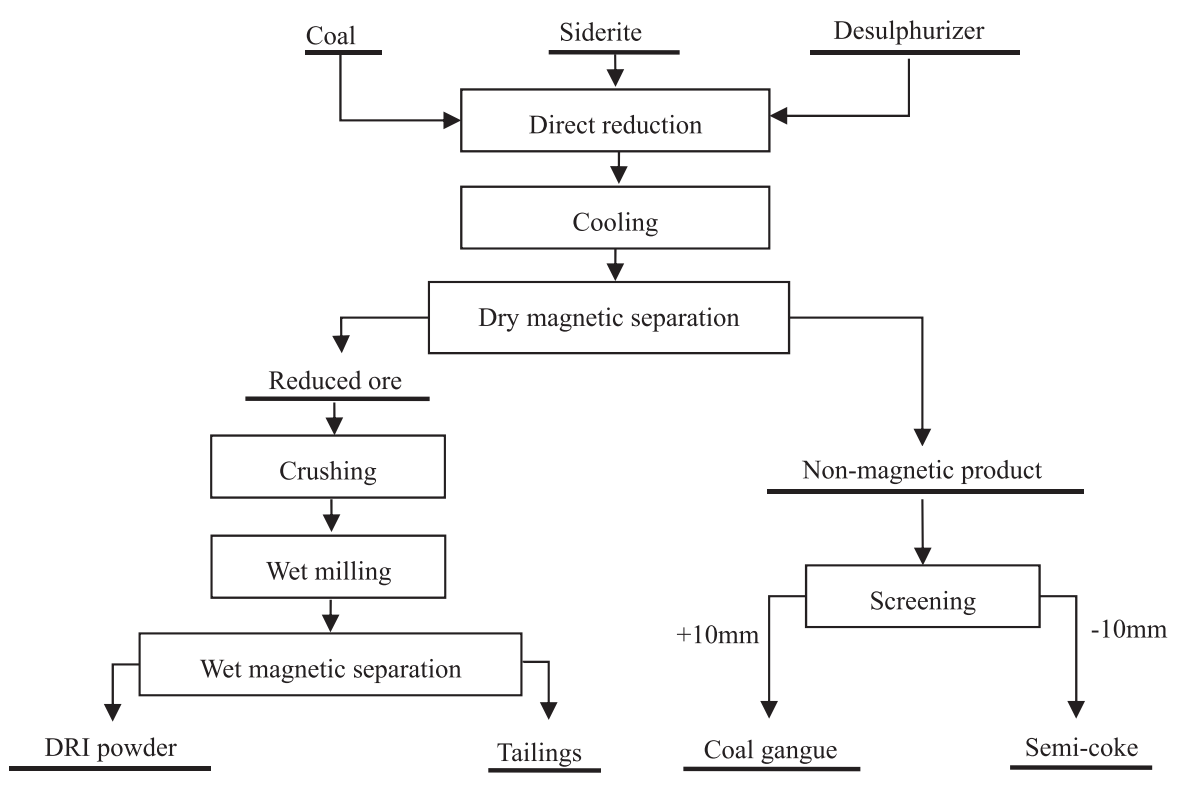

Fig. 2. Test flow sheet of coproduction of DRI powder and semi-coke by excessive coal-based direct reduction process.

into a rotary kiln (bench scale: $\phi 120 \times 200 \mathrm{~mm}$, pilot scale: $\phi 1000 \times 500 \mathrm{~mm})$ for reduction. The amount of coal required for reduction was determined by designed $\mathrm{C} / \mathrm{Fe}$ mass ratio and the desulfurizer was added at designed amount of coal mass. After reduction for pre-set time, the reduced ore and the residual char were discharged and cooled in a container in nitrogen atmosphere, followed by dry magnetic separation ( $0.15 \mathrm{~T}$ of magnetic field intensity). The magnetic reduced ore was crushed to $-1 \mathrm{~mm}$ and wet milled ( $20 \mathrm{~g}$ for bench scale and $200 \mathrm{~g}$ for pilot scale using conical mill), then followed by wet magnetic separation (bench scale: magnetic tube, pilot scale: drum magnetic separator) to yield final DRI concentrate powder. The nonmagnetic product was screened to remove the coal gangue $(+10 \mathrm{~mm})$ and obtain the semi-coke by-product.

\subsection{Characterization Analysis of Products}

The iron grade and metallization degree of reduced ore and DRI concentrate were assayed by chemical titration analysis, mineralogical characteristics of iron product were accomplished by SEM equipped with EDS (FEI Quanta-200).

Proximate analysis (SDTGA 5000, China) and calorific value of coals and semi-coke sample were performed according to GB/T 212-2008 and GB/T 213-2008 for coal respectively. The porous characterization of semi-coke were studied by the standard $\mathrm{N}_{2}$ adsorption technique (Qudrasorb SI, America). The combustion properties were conducted by non-isothermal TG analysis (Netzsch STA449C, Germany) in the air atmosphere. The gas flow rate is $150 \mathrm{ml} / \mathrm{min}$. The temperature increased from room temperature to $1000^{\circ} \mathrm{C}$ with heating rate of $10^{\circ} \mathrm{C} / \mathrm{min}$.

\section{Results and Discussion}

\subsection{Bench Scale Direct Reduction-Magnetic Separa- tion of Siderite Lump Ore}

\subsubsection{Reduction Temperature}

The effects of reduction temperature on the metallization

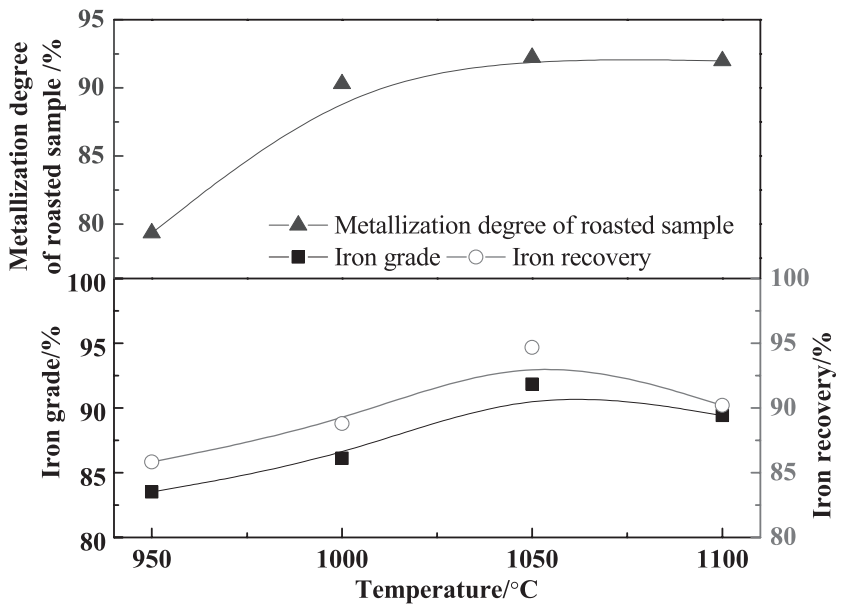

Fig. 3. Effects of reduction temperature on reduction and magnetic separation (Reduction for $140 \mathrm{~min}, \mathrm{C} / \mathrm{Fe}=2.25$, wet grinding at $83.14 \%$ passing $0.074 \mathrm{~mm}$ and magnetic separation at $1000 \mathrm{Gs}$ of magnetic field intensity).

degree and upgrading of iron are shown in Fig. 3. With an increase in reduction temperature from $950^{\circ} \mathrm{C}$ to $1100^{\circ} \mathrm{C}$, the metallization degree increases and keeps almost steady when the temperature is over $1050^{\circ} \mathrm{C}$. In the meantime, the iron grade and recovery gradually clime up to peak of $94.68 \%$ and $91.83 \%$ respectively at $1050^{\circ} \mathrm{C}$, and then drop with further increase of temperature. It can be found the optimum metallization agrees with the best beneficiation of iron at $1050^{\circ} \mathrm{C}$. It is acknowledged that the temperature is one of dominant kinetic parameters for many reactions in the reduction. The thermal decomposition of siderite, the reduction rate of iron oxides and the rate of gasification reaction of coal char could be accelerated considerably by increasing reduction temperature, thus enhancing the growth of metallic iron grains and achieving higher metallization degree. However, further increase in reduction temperature higher than $1050^{\circ} \mathrm{C}$ lead to a slight decline on iron grade and recovery. For this siderite lump, the $\mathrm{SiO}_{2}$ content is as 
high as $10.75 \%$, in reduction process, fayalite is easily to form with the presence of $\mathrm{FeO}$ and $\mathrm{SiO}_{2}$ in reduction temperature range, as indicated by Gibbs Eq. (1) as below: ${ }^{14)}$

$$
2 \mathrm{FeO}+\mathrm{SiO}_{2}=2 \mathrm{FeO} \cdot \mathrm{SiO}_{2} \quad \Delta \mathrm{G}^{\theta}=-33231+15.26 T \ldots(1)
$$

The $\Delta G^{\theta}$ is negative value in the reduction temperature range, indicating the reaction could proceed spontaneously. However, $2 \mathrm{FeO} \cdot \mathrm{SiO}_{2}$ is more difficult to reduce than $\mathrm{FeO}$. So, there is still minor fayalite exist after reduction at $1100^{\circ} \mathrm{C}$ (Fig. 4). It can be seen from the $\mathrm{FeO}-\mathrm{SiO}_{2}$ phase diagram ${ }^{15)}$ (Fig. 5), the fayalite $\left(2 \mathrm{FeO} \cdot \mathrm{SiO}_{2}\right)$ could further react with $\mathrm{FeO}$ or $\mathrm{SiO}_{2}$ to form eutectic crystal $2 \mathrm{FeO} \cdot \mathrm{SiO}_{2}-$ $\mathrm{FeO}$ or $2 \mathrm{FeO} \cdot \mathrm{SiO}_{2}-\mathrm{SiO}_{2}$, both of which have lower melting point below $1200^{\circ} \mathrm{C}$. In rotary kiln reduction process, once the temperature of local point is too high, the fayalite and its eutectic crystal may melt and form liquid phase to wrap the iron, leading the difficulty of iron upgrading. ${ }^{7,8,16)}$ Although the melting temperature of fayalite and its eutectic crystal is higher than $1100^{\circ} \mathrm{C}$, the local overheat problem is inevitable. So, the magnetic separation results at $1100^{\circ} \mathrm{C}$ is slightly decreased.

In addition, too high temperature will bring about a risk of ring formation in rotary kiln and more energy consumption. In consideration of that operation reduction temperature

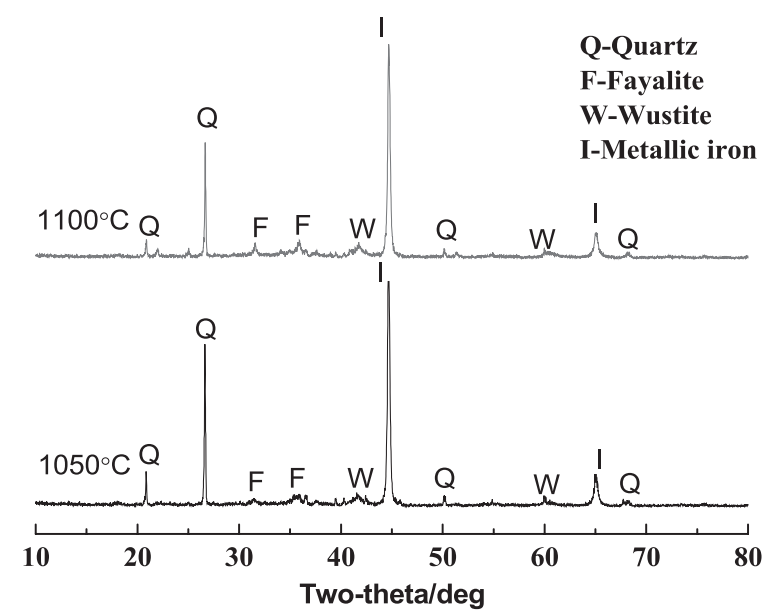

Fig. 4. XRD pattern of roasted ore at different reduction temperature.

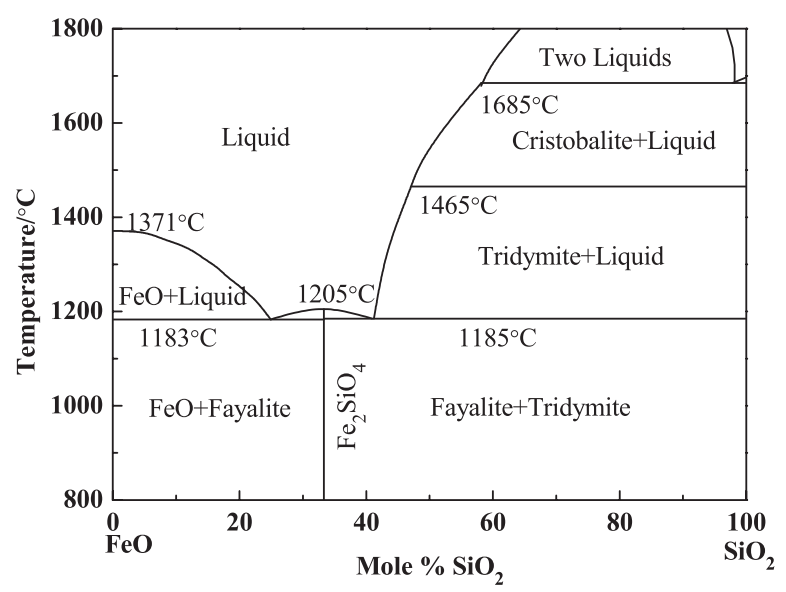

Fig. 5. $\mathrm{FeO}-\mathrm{SiO}_{2}$ Phase diagram. should be lower by $100-150^{\circ} \mathrm{C}$ than the softening temperature of coal ash in rotary kiln, therefore, the optimum reduction temperature is recommended at $1050^{\circ} \mathrm{C}$.

\subsubsection{Reduction Duration}

It can be observed that the metallization degree increases with residence time and the reduction duration has little effects on iron grade and recovery between 80-140 min (Fig. 6). With the prolonging of reduction time, the iron grade increases sluggishly from $89.79 \%$ to $91.83 \%$, with accidental fluctuation at $120 \mathrm{~min}$. Meanwhile, the iron recovery reaches maximum of $95.07 \%$ at $120 \mathrm{~min}$.

Based on our previous research, ${ }^{17)}$ siderite initially decomposed into magnetite in reduction atmosphere, and further reduced step by step as $\mathrm{Fe}_{3} \mathrm{O}_{4} \rightarrow \mathrm{FeO} \rightarrow \mathrm{Fe}$. Because of the effect of heat transfer, the reduction rate of internal layer was slower than the outer layer. At the end of reduction process, the wustite and fayalite in the internal layer of siderite lump were usually trapped by reduced metallic iron, leading to stronger diffusion resistance against reduction gas and slower reduction rate. In addition, over prolonged reduction time weakens the reduction atmosphere and maybe cause the re-oxidization of the metallic particles in the already reduced materials. Furthermore, overlong residence time will reduce the productivity. In the industrial production, the productivity is as important as product quality. Therefore, the optimum duration is proposed between 120-140 $\mathrm{min}$.

\subsubsection{Mass Ratio of Carbon to Iron}

One of the most important parameters affecting the reduction reactions is the mass ratio of carbon to iron $(\mathrm{C} /$ $\mathrm{Fe})$. Strong reduction atmosphere is necessary for reduction of iron oxides. In our experiment, the $\mathrm{C} / \mathrm{Fe}$ mass ratio is intentionally superfluous to recover the iron and carbon simultaneously. As shown in Fig. 7, with an increase in C/ Fe from 1.12 to 2.25 , the metallization degree climes up gradually and reaches above $90 \%$ at 1.86 of $\mathrm{C} / \mathrm{Fe}$, the corresponding iron recovery is elevated evidently from $91.92 \%$ to $94.68 \%$, while the iron grade of concentrate is little affected

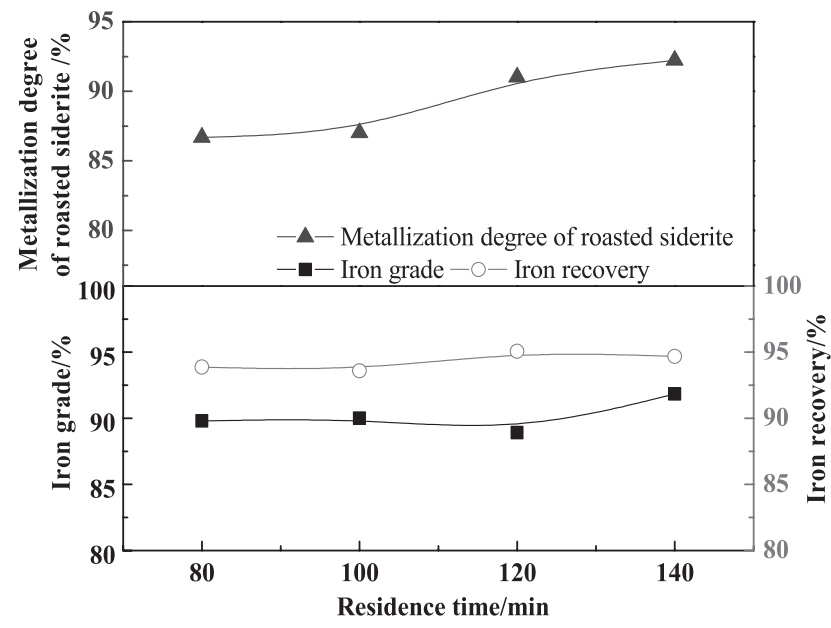

Fig. 6. Effects of reduction duration on reduction and magnetic concentration (Reduction at $1050^{\circ} \mathrm{C}, \mathrm{C} / \mathrm{Fe}=2.25$, wet grinding at $83.14 \%$ passing $0.074 \mathrm{~mm}$ and magnetic separation at $1000 \mathrm{Gs}$ of magnetic field intensity). 


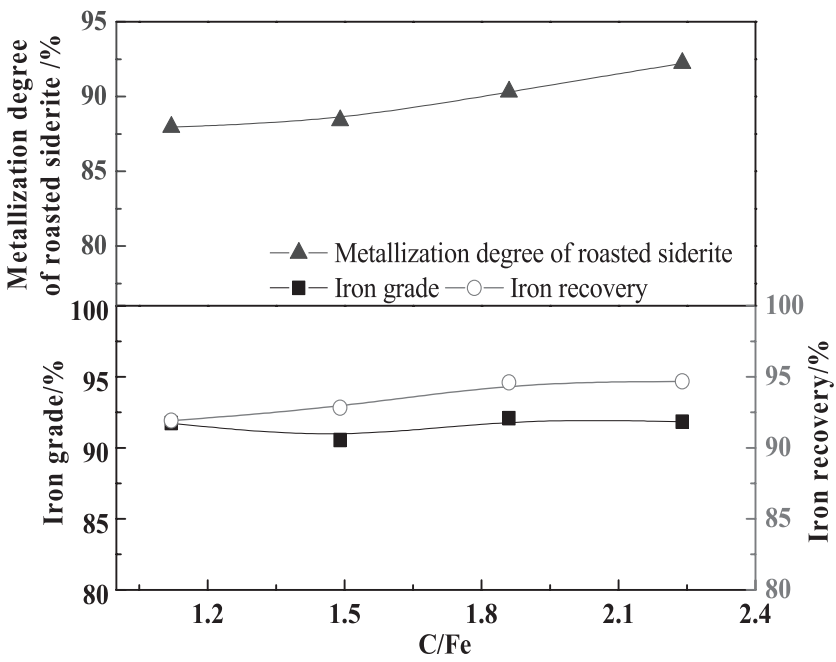

Fig. 7. Effects of $\mathrm{C} / \mathrm{Fe}$ mass ratio on reduction and concentration index (Reduction at $1050^{\circ} \mathrm{C}$ for $140 \mathrm{~min}$, wet grinding at $83.14 \%$ passing $0.074 \mathrm{~mm}$ and magnetic separation at 1000 Gs of magnetic field intensity).

by $\mathrm{C} / \mathrm{Fe}$. From the point of iron upgrading, the $\mathrm{C} / \mathrm{Fe}$ mass ratio of 1.12 is sufficient, but from the point of enhancing coal, the $\mathrm{C} / \mathrm{Fe}$ mass ratio should be elevated. It is noteworthy that the excessive dosage of reductant at this range could provide strong reduction atmosphere for iron ore reduction and avoid the local oxidative exothermic reactions that may cause the ring formation in rotary kiln. In addition, excessive $\mathrm{C} / \mathrm{Fe}$ of this range could enhance coal coking to form high value semi-coke by-product, higher content of carbon in the non-magnetic product after dry magnetic separation possesses higher potential value to offset the cost of excess coal. Admittedly, the $\mathrm{C} / \mathrm{Fe}$ should not be blindly increased. Both the quality and yield of DRI and semi-coke should be considered, as well as the rotary kiln condition. Accordingly, in consideration of the potential value of residual char and productivity of kiln, the $\mathrm{C} / \mathrm{Fe}$ mass ratio is suggested between 1.12-1.86.

\subsubsection{Adding Desulfurizer}

In coal-based direct reduction process, the reduced metallic iron has strong tendency to adsorbe sulfur. So the addition of desulfurizer is indispensable. The effects of desulfurizer dosage on the separation of reduced ore were shown in Fig. 8. The results reveal that the addition of desulfurizer has little effects on iron grade and iron recovery, but has obvious impact on sulfur content of DRI concentrate powder. With an increase in desulfurizer addition from $0 \%$ to $7 \%$, the sulfur in DRI powder drops from $0.30 \%$ to $0.13 \%$.

In consideration of that the size of desulfurizer is -5 $\mathrm{mm}$, the redundant addition will increase the fine particles in rotary kiln, posing threat to ring formation. In addition, excessive desulfurizer amount will add more ash in nonmagnetic fraction, affecting the recovery of carbon. The removal of sulfur should be further improved by grindingmagnetic separation. Besides, the reactor of small scale rotary tube is relatively close without exhausting system, it is estimated the sulfur content in DRI concentrate can be further removed in pilot scale experiments. Given all that,

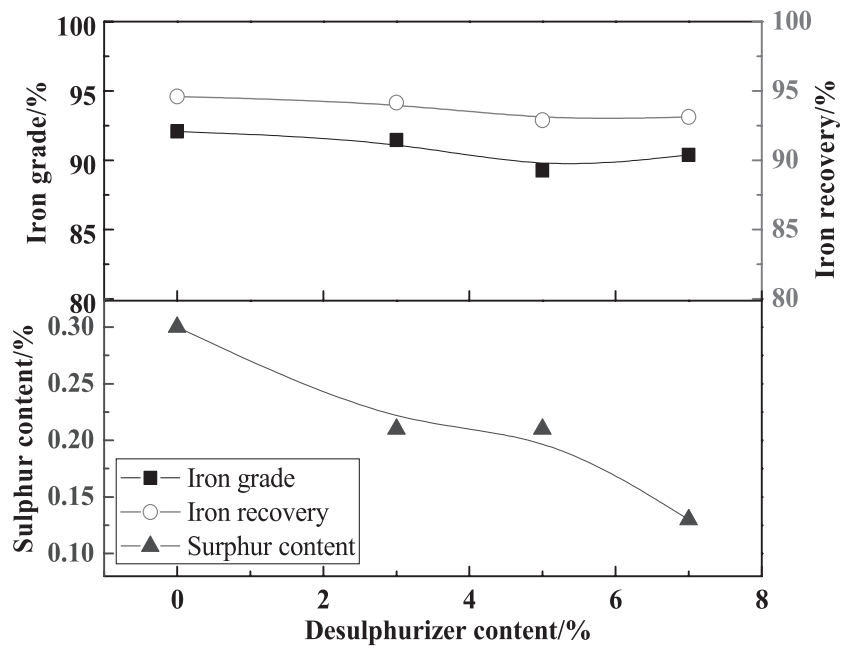

Fig. 8. Effects of desulfurizer on concentration index (Reduction at $1050^{\circ} \mathrm{C}$ for $140 \mathrm{~min}, \mathrm{C} / \mathrm{Fe}=1.86$, wet grinding at $83.14 \%$ passing $0.074 \mathrm{~mm}$ and magnetic separation at $1000 \mathrm{Gs}$ of magnetic field intensity).

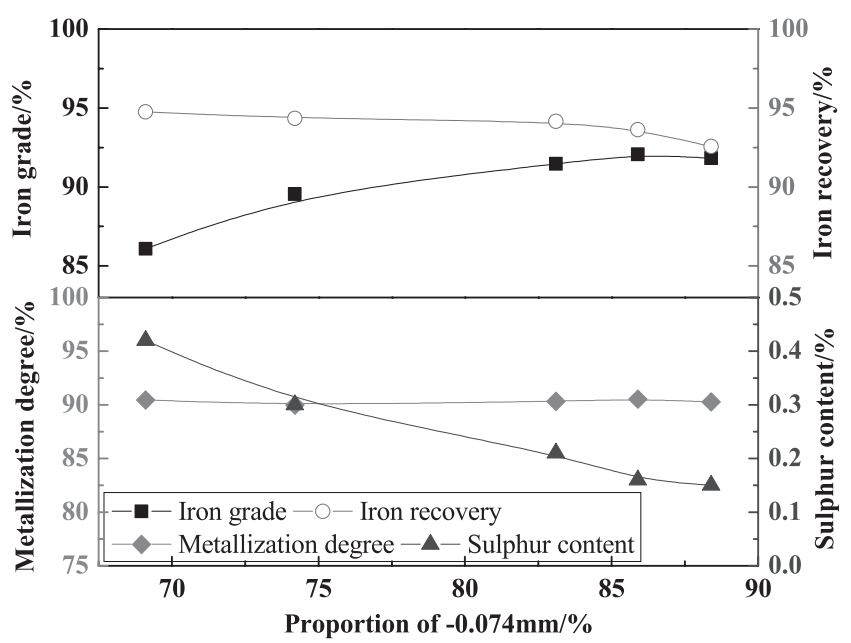

Fig. 9. Effects of grinding fineness on concentration index (Reduction at $1050^{\circ} \mathrm{C}$ for $140 \mathrm{~min}$ and $\mathrm{C} / \mathrm{Fe}=1.86,3 \%$ desulfurizer, wet magnetic separation at $1000 \mathrm{Gs}$ of magnetic field intensity).

$3 \%$ desulfurizer is recommended to add in kiln tube.

\subsubsection{Wet Magnetic Separation of Reduced Ore}

In wet magnetic separation process, full liberation of metallic iron from gangue at appropriate grinding fineness is the prerequisite to achieve optimum beneficiation results. As shown in Fig. 9, with an increase in grinding fineness, the iron grade is elevated apparently while the iron recovery slightly declined and the iron metallization degree of DRI concentrate keeps steady. It is acknowledged that if the particle size is not fine enough, the gangue and valuable minerals will not be dissociated completely, resulting in difficulty of achieving effective separation and enrichment. However, if the grinding fineness is too small, the target minerals will be over-ground and argillized, leading to trapping of impurities. It also can be revealed that the increase of fineness has apparently improved the removal of sulfur from DRI concentrate. The effects of field intensity of wet magnetic 
separation on DRI concentrate were given in Fig. 10. It is revealed that the field intensity has little effects on separation results between 500-2 000 Gs range.

Overall, the optimized conditions of bench scale experiments were suggested as follows: reducing at $1050^{\circ} \mathrm{C}$ for $140 \mathrm{~min}$ with $\mathrm{C} / \mathrm{Fe}=1.86$, and $3 \%$ desulfurizer addition, grinding at $85.92 \%$ passing $0.075 \mathrm{~mm}$ and magnetic field intensity around 1000 Gs.

\subsection{Analysis of Reduction Products}

The final products after magnetic separation include DRI concentrate powder, tailings and residual coal. The magnetic separation effects and chemical compositions of products are exhibited in Tables $\mathbf{5}$ and $\mathbf{6}$. It can be seen that the valuable iron element is enriched effectively in the DRI concentrate assaying $92.06 \% \mathrm{Fe}_{\text {total }}$ with $90.52 \%$ metallization degree, demonstrating the concentrate product is a good burden of electrical furnace for steelmaking. The gangue minerals and impurities are mainly rejected into the tailings which could be utilized to produce cementitious materials.

The yield of non-magnetic product occupies 56.04\% in the dry magnetic separation of reduced materials and

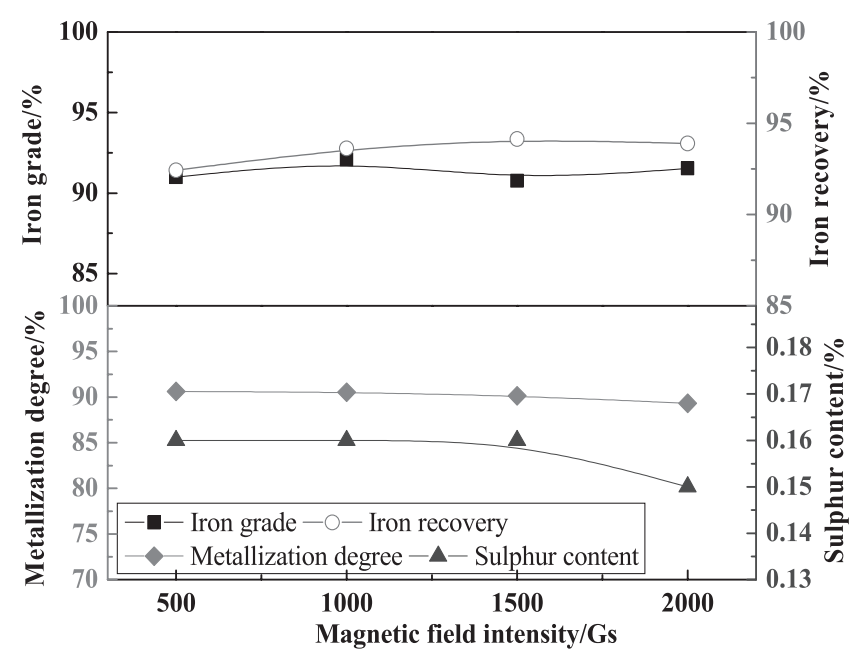

Fig. 10. Effects of field intensity on concentration index (Reduction at $1050{ }^{\circ} \mathrm{C}$ for $140 \mathrm{~min}$ and $\mathrm{C} / \mathrm{Fe}=1.86,3 \%$ desulfurizer, grinding at $85.92 \%$ passing $0.074 \mathrm{~mm}$ ).

Table 5. Products from the coal-based direct reduction-magnetic separation process.

\begin{tabular}{cccc}
\hline Products & TFe/\% & Yield $/ \%$ & Iron recovery/\% \\
\hline $\begin{array}{c}\text { DRI concentrate } \\
\text { Tailings of wet magnetic } \\
\text { separation }\end{array}$ & 92.06 & 28.90 & 85.94 \\
Non-magnetic product & 12.04 & 15.06 & 5.86 \\
\hline
\end{tabular}

it assaying 50.36\% $\mathrm{FC}_{\mathrm{d}}, 43.96 \% \mathrm{~A}_{\mathrm{d}}$ and $5.68 \% \mathrm{~V}_{\mathrm{d}}$, in proximate analysis, with very low content of volatile present after pyrolysis at high temperature, which reveals the non-magnetic product has certain potential utilization value after further upgrading by gravity separation and could partly replace coke breeze in the sintering of iron ore fines for ironmaking. ${ }^{18,19)}$

In order to have a deep insight into the DRI concentrate, SEM-EDS analysis was conducted to reveal the element distribution. The backscattered-electron diffractions (Fig. 11) show that the grain size of metallic iron is universally between 10-30 $\mu \mathrm{m}$, while calcium, magnesium, manganese and sulfur element exist in extremely fine dissemination, leading to difficulty in eliminating them completely by further grinding-magnetic separation, proving that siderite ore is difficult to beneficiate by traditional upgrading processes. The findings justified the substitution of impurities $\mathrm{Ca}^{2+}$, $\mathrm{Mg}^{2+}$ and $\mathrm{Mn}^{2+}$ existing in carbonate lattice for $\mathrm{Fe}^{2+}$. The EDS analysis of DRI concentrate (Fig. 12) indicates minor impurities containing calcium, manganese and magnesium are eliminated from iron grains to form complex fayalite with wustite (B point). Some complex fayalite distributes at brim of iron grains or even wrapped in the iron grains, especially the latter is difficult to reduce.

\subsection{Production of Semi-coke as By Product in Pilot Scale Process}

Based on the bench scale rotary tube experiments, the pilot scale verification tests were conducted likewise after a series of optimization experiments of technical parameters. The results show that final DRI concentrate assaying $92.62 \% \mathrm{Fe}, 93.51 \%$ metallization degree was obtained at a total iron recovery of $82.98 \%$ under the following conditions: siderite lump of 5-25 mm, reduced at $1050^{\circ} \mathrm{C}$ for $120 \mathrm{~min}, \mathrm{C} / \mathrm{Fe}=1.50$ and $6 \%$ desulfurizer, dry magnetic at $0.15 \mathrm{~T}$ field intensity, the first stage wet grinding of reduced siderite sample up to $50 \%$ passing $0.074 \mathrm{~mm}$, separating at $0.08 \mathrm{~T}$ magnetic field intensity, and the second one up to $90 \%$ passing $0.074 \mathrm{~mm}$, separating at $0.043 \mathrm{~T}$. The chemical compositions of final DRI concentrate product are tabulated in Table 7, it is a good quality DRI powder with high iron grade and low impurities.

In consideration of the potential utilization value of residual char and due to the better reactivity and lower sulfur content, the Shenfu bitumite coal was selected as reductant in contrast tests. The effects of $\mathrm{C} / \mathrm{Fe}$ mass ratio on reduction and separation were depictured in Fig. 13. From the perspective of beneficiation of siderite, with an increase in $\mathrm{C} / \mathrm{Fe}$ mass ratio, the changes of metallization degree of roasted ore, iron grade and recovery of wet magnetic separation are not significant in this range. The reduction and magnetic separation results were satisfied only at $1.0 \mathrm{C} / \mathrm{Fe}$

Table 6. Chemical compositions of dry and wet magnetic separation products/\%.

\begin{tabular}{ccccccccccc}
\hline Products & $\mathrm{TFe}$ & $\mathrm{MFe}$ & $\mathrm{SiO}_{2}$ & $\mathrm{Al}_{2} \mathrm{O}_{3}$ & $\mathrm{CaO}$ & $\mathrm{MgO}$ & $\mathrm{MnO}$ & $\mathrm{P}$ & $\mathrm{S}$ & $\mathrm{K}_{2} \mathrm{O}$ \\
\hline DRI Concentrate & 92.06 & 83.33 & 1.67 & 0.14 & 2.02 & 1.58 & 2.35 & 0.01 & 0.16 & 0.10 \\
Tailings of wet magnetic separation & 12.04 & - & 45.14 & 7.04 & 12.47 & 4.21 & 7.21 & 0.09 & 1.36 & 1.98 \\
Non-magnetic product & 10.30 & - & 38.32 & 14.97 & 19.75 & 4.26 & - & 0.19 & 1.31 & 1.35 \\
\hline
\end{tabular}



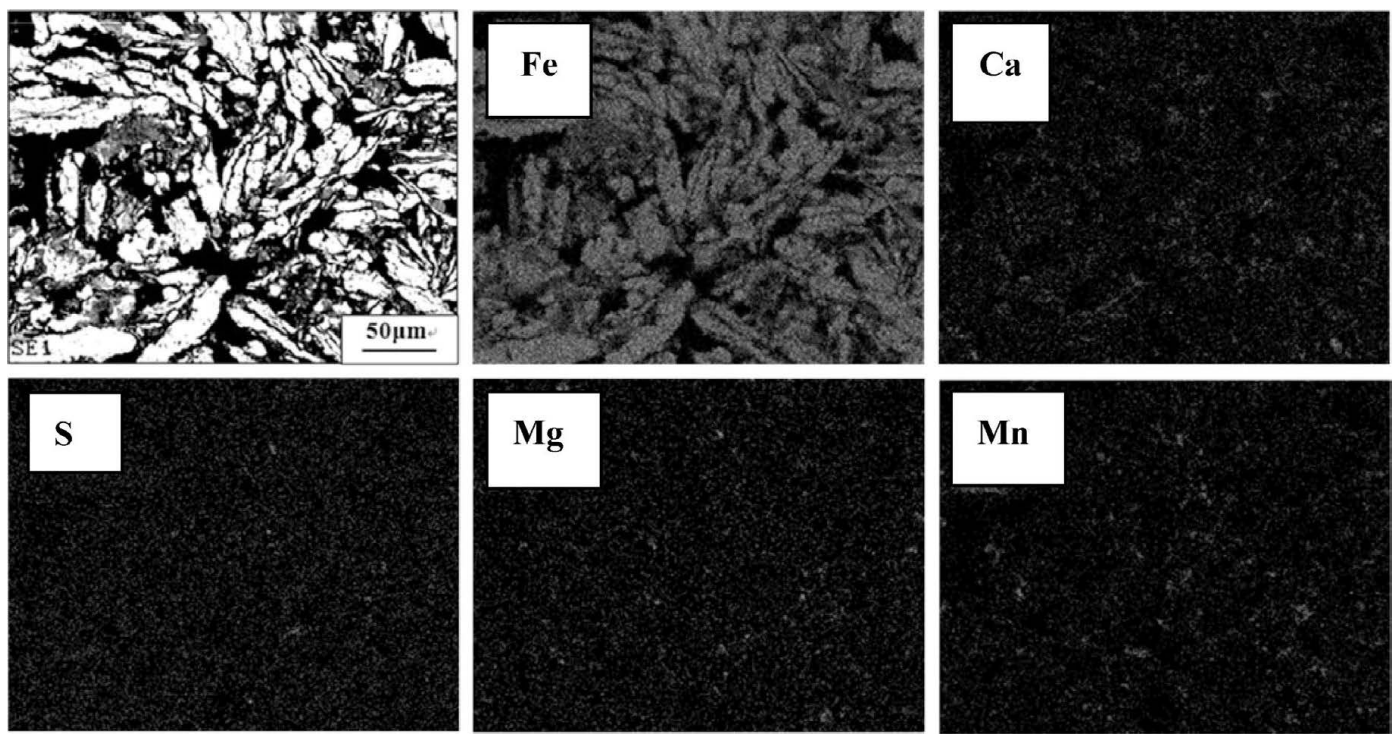

Fig. 11. Element backscattered-electron diffraction of DRI concentrate.

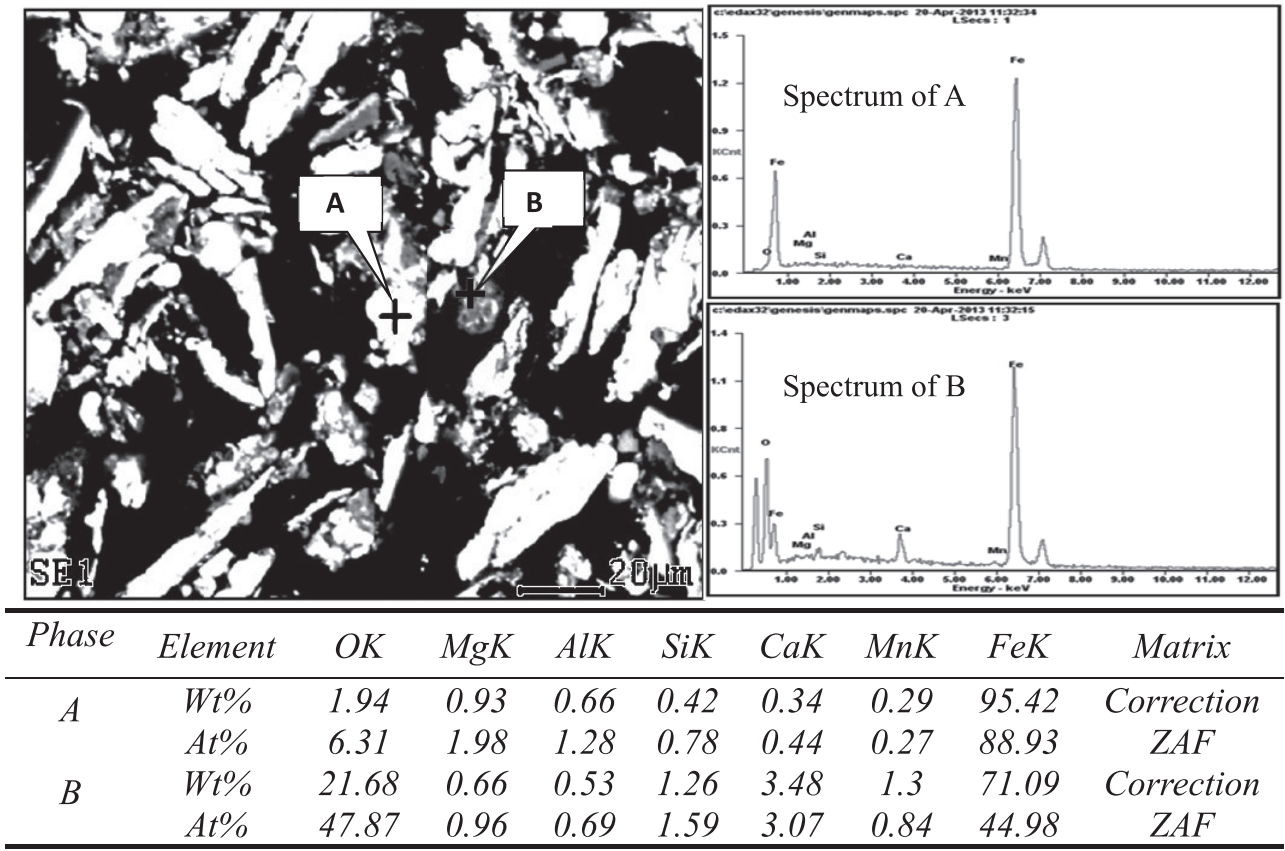

Fig. 12. SEM and EDS analysis of DRI concentrate.

Table 7. Chemical compositions of final concentrate product $/ \%$.

\begin{tabular}{ccccccccc}
\hline $\mathrm{TFe}$ & $\mathrm{MFe}$ & $\mathrm{SiO}_{2}$ & $\mathrm{Al}_{2} \mathrm{O}_{3}$ & $\mathrm{CaO}$ & $\mathrm{MgO}$ & $\mathrm{MnO}$ & $\mathrm{P}$ & $\mathrm{S}$ \\
\hline 92.62 & 86.61 & 1.54 & 0.32 & 0.99 & 0.70 & 1.34 & 0.013 & 0.058
\end{tabular}

mass ratio. However, from the point of coal upgrading, the over dosage of coal is essential.

In coal-based direct reduction production, the lump coal is charged from the rotary kiln end and undergoes a series of physical changes and chemical reactions at high temperature involving pyrolysis and gasification. Any gasification reaction typically consists of initial rapid pyrolysis of carbonbased material (coal $\rightarrow$ char + tar + gas) and the subsequent gasification of the resultant char $\left(\mathrm{C}+\mathrm{CO}_{2}=2 \mathrm{CO}\right){ }^{20-23)}$ The carbon dioxide derived from the reduction of iron oxides is the gasification agent of coal char. In traditional coal-based

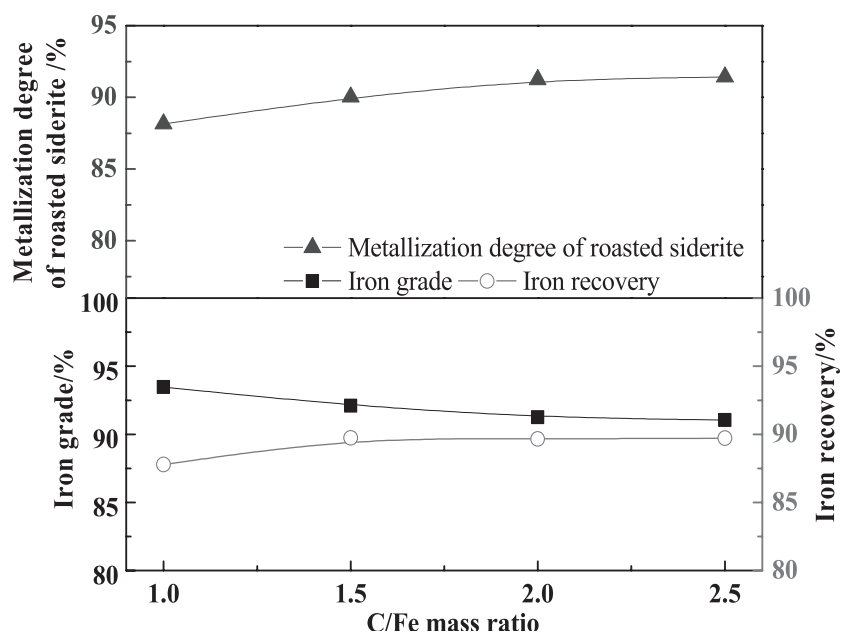

Fig. 13. Effects of $\mathrm{C} / \mathrm{Fe}$ mass ratio on reduction and magnetic concentration index in pilot scale test. 
direct reduction of iron oxides, the $\mathrm{C} / \mathrm{Fe}$ ratio is required as less as possible to reduce the energy consumption and material cost. The majority carbon involves in the gasification after pyrolysis to provide $\mathrm{CO}$ for iron oxides reduction, so the ash dominates the non-magnetic products with less value. In our study, the excessive dosage of reductant was intentionally applied in order to provide strong reduction atmosphere for iron ore reduction and avoid the ring formation in rotary kiln caused by local oxidative exothermic reactions. From another aspect, the higher $\mathrm{C} / \mathrm{Fe}$ will bring about the higher content of carbon in the non-magnetic product after dry magnetic separation, and the upgraded coal char possesses higher potential value to offset the cost of excessive lump coal.

As shown in Fig. 14, with an increase in the $\mathrm{C} / \mathrm{Fe}$ mass ratio from 1.0 to 2.5 , the fixed carbon content raises significantly from $32.00 \%$ to $62.29 \%$. The volatile content of nonmagnetic product is less than $4 \%$ attributing to the pyrolysis at high temperature. Since the breakage and pulverization of coal occur in pyrolysis and gasification process at high temperature, the remained $+10 \mathrm{~mm}$ fraction mainly consists of coal gangue. As shown in Table 8, it is noted that the yield of $+10 \mathrm{~mm}$ fraction occupies around one third of nonmagnetic products and contains much higher ash, assaying $75.04 \%$. Obviously, most of fixed carbon is enriched in 3-10 $\mathrm{mm}$ size fractions. Table 9 illustrates that the fixed carbon content of the non-magnetic products can be raised significantly after discarding the $+10 \mathrm{~mm}$ size gangue by screening. The obtained fraction after removing $+10 \mathrm{~mm}$ gangue is semi-coke that is the recycling objective to study.

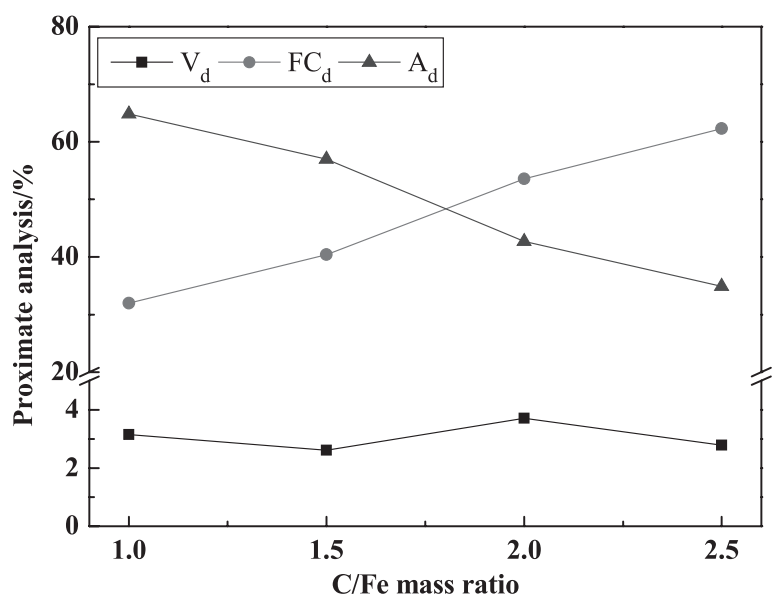

Fig. 14. Effects of $\mathrm{C} / \mathrm{Fe}$ mass ratio in reduction process on proximate analysis of non-magnetic products.

Table 8. Proximate analysis of non-magnetic products in different size fraction $(\mathrm{C} / \mathrm{Fe}=2.50)$.

\begin{tabular}{ccccc}
\hline Size $/ \mathrm{mm}$ & $\mathrm{Yield} / \%$ & $\mathrm{~V}_{\mathrm{d}} / \%$ & $\mathrm{FC}_{\mathrm{d}} / \%$ & $\mathrm{~A}_{\mathrm{d}} / \%$ \\
\hline+10 & 26.33 & 1.33 & 23.63 & 75.04 \\
$5-10$ & 41.31 & 3.57 & 80.33 & 16.10 \\
$3-5$ & 15.40 & 3.43 & 82.52 & 14.05 \\
-3 & 16.95 & 2.59 & 60.01 & 37.40 \\
Total & 100 & 2.79 & 62.29 & 34.92 \\
\hline
\end{tabular}

The iron balance of whole process is exhibited in Fig. 15. It is emphasized that once $1 \mathrm{Kg}$ DRI powder is produced, $1.82 \mathrm{Kg}$ non-magnetic products are generated at the same time and $1.34 \mathrm{Kg}$ semi-coke with high carbon is obtained by removing the $+10 \mathrm{~mm}$ size fraction. The characterization of semi-coke should be conducted to know how to use this new type solid fuel.

\subsection{Characterization of Semi-coke Product}

The comparison of the proximate analysis of semi-coke and a traditional coke breeze is presented in Table 10. It is found that semi-coke possesses very similar proximate analysis index with coke breeze used in iron ore sintering process, only besides the fixed carbon content is $4 \%$ lower than the latter. The gross calorific value of semi-coke is $28.10 \mathrm{MJ} / \mathrm{kg}$ which is close to that of coke breeze when the $\mathrm{C} / \mathrm{Fe}$ mass ratio of reduction is 2.50 . Therefore, the subsequent characterization in this paper were focused on the comparison between a domestic sinter coke breeze and this semi-coke to explore the feasibility of semi-coke as partial replacement of solid fuel for sintering.

The compositions of fuel ash are listed in Table 11. It is shown that semi-coke contains lower content of $\mathrm{SiO}_{2}$, $\mathrm{Al}_{2} \mathrm{O}_{3}, \mathrm{~S}$ and much higher content of $\mathrm{CaO}$ and $\mathrm{MgO}$ in ash, which will contribute to saving fluxes addition and cutting production cost. Recycling of this semi-coke to sintering process is attractive due to the higher basicity of its ash.

Some physical properties of coke breeze and semi-coke relevant to granulation and sintering were determined and presented in Table 12. The bulk density of coke breeze and semi-coke are $0.75 \mathrm{~g} / \mathrm{cm}^{3}$ and $0.53 \mathrm{~g} / \mathrm{cm}^{3}$, respectively, which implies semi-coke has looser and more porous structure than common coke breeze. Semi-coke occupies more space volume compared with coke at fixed mass. The specific surface areas and pore volume analysis also confirm the flourishing porous structure of semi-coke. The BET specific surface areas of semi-coke reach as high as $251.77 \mathrm{~m}^{2} / \mathrm{g}$, which is two order of magnitude higher than that of coke breeze (only $1.89 \mathrm{~m}^{2} / \mathrm{g}$ ). Also, the total pore volume of common coke breeze and semi-coke are $0.002 \mathrm{cc} / \mathrm{g}$ and 0.233 $\mathrm{cc} / \mathrm{g}$, respectively. Therefore, due to the well-developed porous structure, the semi-coke possesses much higher maximum capillary and molecular moisture, which maybe significantly affect the granulation and sintering.

Non-isothermal TG analysis was conducted to investigate the combustion behavior of semi-coke and coke breeze. As shown in Table 13, the starting temperature $\left(\mathrm{T}_{\mathrm{s}}\right)$ and ignition temperature $\left(\mathrm{T}_{\mathrm{i}}\right)$ of semi-coke are slightly lower than those of coke breeze, but the burnout temperature $\left(\mathrm{T}_{\mathrm{e}}\right)$ is lower than $231^{\circ} \mathrm{C}$. It is obvious to find that the combustion interval of semi-coke is only $105^{\circ} \mathrm{C}$, which is much narrower than that of coke breeze. The narrower combustion zone of semi-

Table 9. Comparison of fixed carbon content after removing +10 $\mathrm{mm}$ fraction (mass $\%$ ).

\begin{tabular}{ccccc}
\hline $\mathrm{C} / \mathrm{Fe}$ & 1.0 & 1.5 & 2.0 & 2.5 \\
\hline Total FC $\mathrm{d}$ of non-magnetic products & 32.00 & 40.40 & 53.59 & 62.29 \\
$\mathrm{FC}_{\mathrm{d}}$ of semi-coke $(-10 \mathrm{~mm})$ & 44.40 & 53.20 & 68.67 & 76.11 \\
\hline
\end{tabular}




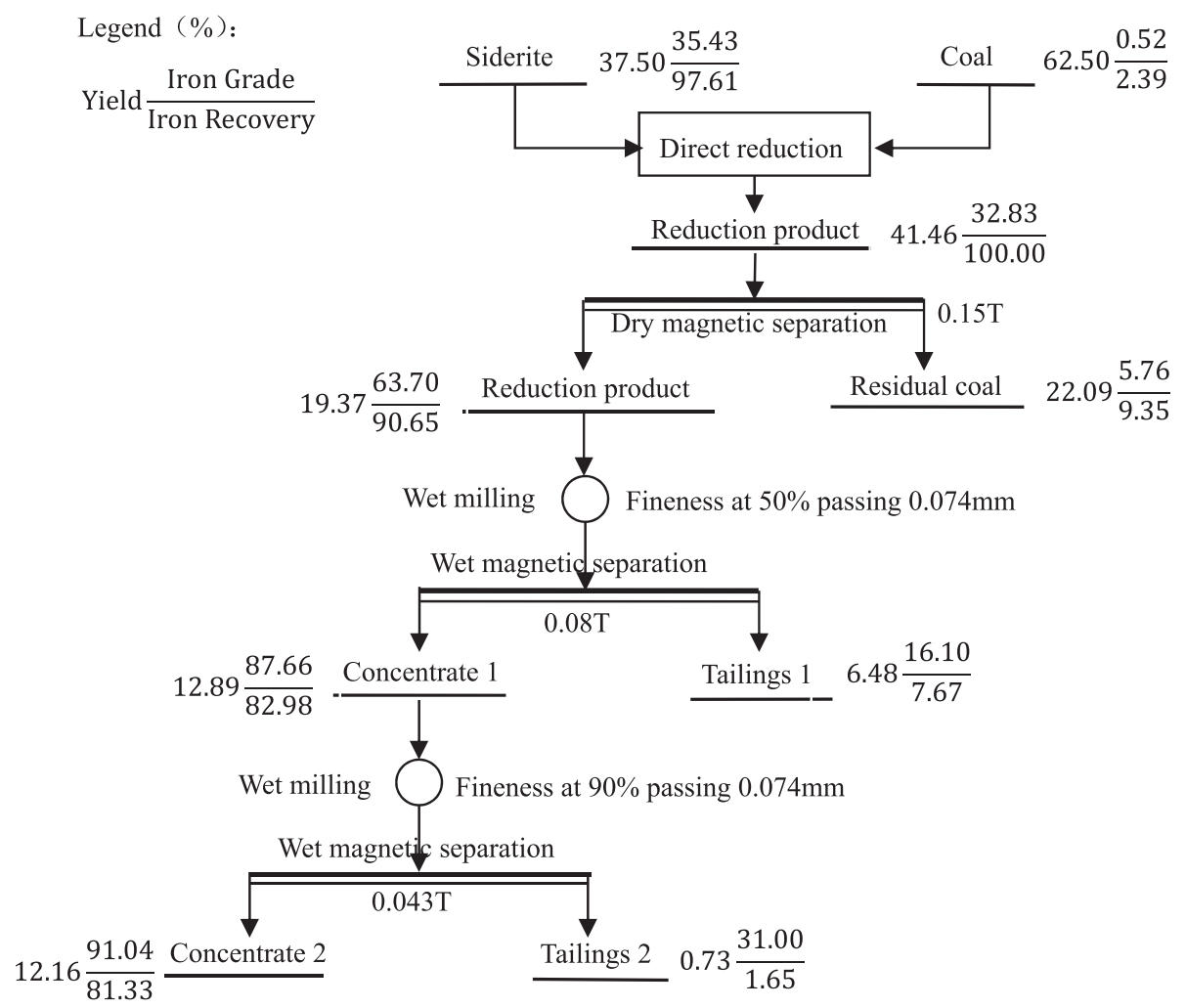

Fig. 15. Iron balance of complete flow process (Reduced at $1050^{\circ} \mathrm{C}$ for $120 \mathrm{~min}, \mathrm{C} / \mathrm{Fe}=2.50$, and $6 \%$ desulfurizer)

Table 10. Proximate analysis of coke breeze and semi-coke.

\begin{tabular}{cccccc}
\hline Samples & $\mathrm{A}_{\mathrm{d}} / \%$ & $\mathrm{~V}_{\mathrm{d}} / \%$ & $\mathrm{FC}_{\mathrm{d}} / \%$ & $\mathrm{~S}_{\mathrm{t}, \mathrm{ad}} / \%$ & $\mathrm{Q}_{\mathrm{gr}, \mathrm{r}, \mathrm{d}}(\mathrm{MJ} / \mathrm{kg})$ \\
\hline Coke breeze & 17.32 & 2.39 & 80.29 & 0.40 & 28.36 \\
Semi-coke & 20.46 & 3.43 & 76.11 & 0.30 & 28.10 \\
\hline
\end{tabular}

Note: $\mathrm{Q}_{\mathrm{gr}, \mathrm{v}, \mathrm{d}^{-}}$Gross calorific value in isovolumetric dried basis

Table 11. Chemical compositions of semi-coke and coke breeze ash (mass\%).

\begin{tabular}{ccccccc}
\hline Samples & $\mathrm{Fe}_{2} \mathrm{O}_{3}$ & $\mathrm{SiO}_{2}$ & $\mathrm{Al}_{2} \mathrm{O}_{3}$ & $\mathrm{CaO}$ & $\mathrm{MgO}$ & $\mathrm{S}$ \\
\hline Coke breeze & 17.13 & 43.76 & 33.07 & 2.54 & 0.58 & 2.91 \\
Semi-coke & 10.70 & 40.09 & 16.95 & 19.50 & 0.99 & 1.78 \\
\hline
\end{tabular}

coke is attributed to the faster combustion reaction rate. The maximum combustion rate of semi-coke is over twice of coke breeze. Also, the comprehensive combustion index $\mathrm{P}^{24)}$ of semi-coke is four times higher than coke breeze, revealing that semi-coke has superior combustion properties. All of these findings imply that the flame speed of sintering could be elevated to some extent and asynchrony of flame front and heat transfer front is prone to occurring when replacing coke breeze by semi-coke. Therefore, the potential negative effects of the high reactivity on sintering process could be weakened by adequately coarsening the size of semi-coke. However, the sinter experiments should be further conducted to verify the possibility of semi-coke as solid fuel in iron ore sintering in the future.
Table 12. Physical properties of semi-coke and coke breeze.

\begin{tabular}{|c|c|c|c|c|c|}
\hline Samples & $\begin{array}{l}\text { Bulk } \\
\text { density/ } \\
\left(\mathrm{g} / \mathrm{cm}^{3}\right)\end{array}$ & $\begin{array}{c}\text { Max. } \\
\text { Capillary } \\
\text { Moisture/\% }\end{array}$ & $\begin{array}{c}\text { Max. } \\
\text { Molecular } \\
\text { Moisture/\% }\end{array}$ & $\begin{array}{c}\mathrm{BET} / \\
\left(\mathrm{m}^{2} / \mathrm{g}\right)\end{array}$ & $\begin{array}{c}\text { Total pore } \\
\text { volume/ } \\
\text { (cc/g) }\end{array}$ \\
\hline $\begin{array}{c}\text { Coke } \\
\text { breeze }\end{array}$ & 0 & $32.4 J$ & 6.7 & 1.89 & 0.002 \\
\hline Semi-coke & 0.53 & 62.29 & 36.51 & 251.77 & 0.233 \\
\hline
\end{tabular}

Table 13. Combustion properties of semi-coke and coke breeze.

\begin{tabular}{cccccc}
\hline \multirow{2}{*}{ Samples } & \multicolumn{5}{c}{ combustion properties } \\
\cline { 2 - 6 } & $\mathrm{T}_{\mathrm{s}} /{ }^{\circ} \mathrm{C}$ & $\mathrm{T}_{\mathrm{i}} /{ }^{\circ} \mathrm{C}$ & $\mathrm{T}_{\mathrm{e}} /{ }^{\circ} \mathrm{C}$ & $\mathrm{V}_{\max } /\left(\% \cdot \mathrm{min}^{-1}\right)$ & $\mathrm{P} / 10^{-8}$ \\
\hline Semi-coke & 380 & 518 & 623 & 7.41 & 4.34 \\
Coke breeze & 389 & 547 & 854 & 3.02 & 1.08 \\
\hline
\end{tabular}

Note: $T_{\mathrm{s}}$-starting temperature, $\mathrm{T}_{\mathrm{i}}$-ignition temperature, $\mathrm{T}_{\mathrm{e}}$-burnout temperature, $\mathrm{V}_{\max }$-maximum combustion rate, $\mathrm{P}$-comprehensive combustion index

\section{Conclusions}

An integrated process was developed to produce DRI powder and semi-coke simultaneously from the excessive coal-based direct reduction of siderite ore in rotary kiln. The optimization of reduction and magnetic separation process parameters was performed and the characterization of semi-coke was conducted. Some conclusions are drawn as follows:

(1) An effective process of excessive coal-based direct reduction-magnetic separation was developed to beneficiate 
siderite lump ore and upgrade low rank coal. The optimum process parameters in bench scale were proposed as the following: reducing at $1050^{\circ} \mathrm{C}$ for $140 \mathrm{~min}, \mathrm{C} / \mathrm{Fe}=1.86$, $3 \%$ desulfurizer, wet grinding of reduced sample at $85.92 \%$ passing $0.074 \mathrm{~mm}$ and magnetic separation in Davis tube at 1000 Gs magnetic field intensity. DRI powder assaying $92.06 \% \mathrm{Fe}$ and $90.52 \%$ metallization degree was manufactured at an iron recovery of $85.94 \%$. Based on the bench scale tests, the pilot scale verification tests were conducted and final DRI powder assaying 92.62\% Fe and 93.51\% metallization degree was obtained at total iron recovery of $82.98 \%$. The process provides a feasible way to manufacture good quality burdens for electric furnace to make special steel from siderite ores.

(2) The semi-coke as a by-product recovered from the direct reduction process at $\mathrm{C} / \mathrm{Fe}$ mass ratio of 2.50 possesses similar proximate analysis indexes to traditional coke breeze. The characterization of semi-coke indicates it is an attractive alternative solid fuel in the iron ore sintering to reduce coke breeze usage and flue gas emissions.

(3) Based on the investigations in this paper, the laboratorial sinter pot experiments will be further conducted to explore the feasibility of substitution of semi-coke for coke breeze.

\section{Acknowledgments}

The authors are grateful for the financial support provided by the China Torch Program (No. 2011GH561685).

\section{REFERENCES}

1) P. H. Yao, K. N. Wang, C. L. Du, Z. T. Lin and X. Song: Records of China's Iron Ore Deposits, Metallurgical Industry Press, Beijing, (1993), 20 (in Chinese).
2) Y. C. Zhang, X. H. Yang, N. C. Shi and Z. S. Ma: Metal Mine, 31 (2001), 48 (in Chinese).

3) L. Q. Luo: Metal Mine, 36 (2006), 68 (in Chinese).

4) X. Y. Liu, Y. F. Yu and W. Chen: Metal Mine, 39 (2009), 84 (in Chinese).

5) L. Q. Luo, J. S. Zhang, Y. Y. Gao and Y. F. Yu: Metal Mine, 34 (2004), 28 (in Chinese).

6) Z. Z. Zhu and B. H. Zhang: J. Chongqing Univ. Technol., 21 (1998), 101 (in Chinese).

7) Y. X. Wei, T. C. Sun, J. Kou and W. Yu: Chin. J. Process Eng., 11 (2011), 795 (in Chinese)

8) D. J. Zhang, D. F. Chen, C. S. Xu, Z. M. Zhang, M. F. Luo, Y. X. Ye, F. S. Zheng and H. B. Zhang: Chin. J. Process Eng., 9 (2009), 152 (in Chinese).

9) S. F. Yan, T. C. Sun, J. Kou and Y. Xu: Metal Mine, 40 (2011), 89 (in Chinese).

10) M. A. Diez, R. Alvarez and C. Barriocanal: Int. J. Coal Geol., 50 (2002), 389

11) D. Q. Zhu, Y. H. Luo and J. Pan: 5th Int. Symp. High-Temperature Metallurgical Processing, John Wiley \& Sons, Inc., Hoboken, (2014), 231.

12) D. Q. Zhu, X. L. Zhou, J. Pan and Y. H. Luo: Miner. Proc. Extr. Metall., 123 (2014), 246.

13) J. Wang, T. Sakakura, N. Ishizawa and H. Eba: 3rd Int. Cong. on Ceramics (ICC3), IOP Publishing Ltd, UK, (2011), 022011.

14) S. F. Yan, T. C. Sun and Y. Xu: Metal Mine, 41 (2012), 67 (in Chinese).

15) R. A. Cruz, S. A. Romero, R. M. Vargas and L. M. Hallen: $J$. Non-Cryst. Solids, 351 (2005), 1359.

16) X. Y. Zhang, Y. X. Li and H. Li: Bull. Chin. Ceram. Soc., 32 (2013), 25 (in Chinese)

17) D. Q. Zhu, Y. H. Luo, J. Pan and X. L. Zhou: High Temp. Mater. Process, (2015), DOI: 10.1515/HTMP-2014-0176.

18) L. L. Fu, T. Sun, J. J. Fang, Y. B. Xu, J. S. Fu and W. L. Zhai: Henan Metall., 20 (2012), No. 4, 6 (in Chinese).

19) P. A. Botha: J. S. Afr. Inst. Min. Metall., 93 (1993), 13.

20) M. Isao, K. Daizo and F. Takehiko: Ind. Eng. Chem. Res, 26 (1987), 91.

21) Y. T. Kim, D. K. Seo and J. Hwang: Eenerg. Fuel., 25 (2011), 5044.

22) A. Goyal, R. F. Zabransky and A. Rehmat: Ind. Eng. Chem. Res., 28 (1989), 1767.

23) F. F. Min, M. X. Zhang, Y. Zhang, Y. Cao and W. P. Pan: J. Anal. Appl. Pyrol., 92 (2011), 250.

24) Q. H. Nie, S. Z. Sun, Z. Q. Li, X. J. Zhang, S. H. Wu and Y. K. Qin: J. Combust. Sci. Technol., 7 (2001), 72 (in Chinese). 